Wetland Techniques 

James T. Anderson - Craig A. Davis

Editors

\section{Wetland Techniques}

Volume 3: Applications and Management

睹 Springer 


\author{
Editors \\ James T. Anderson \\ Forestry and Natural Resources \\ and Environmental Research Center \\ West Virginia University \\ Morgantown, WV, USA
}

\author{
Craig A. Davis \\ Department of Natural Resource Ecology \\ and Management \\ Oklahoma State University \\ Stillwater, OK, USA
}

\author{
ISBN 978-94-007-6906-9 \\ DOI 10.1007/978-94-007-6907-6 \\ Springer Dordrecht Heidelberg New York London \\ ISBN 978-94-007-6907-6 (eBook)
}

\section{(C) Springer Science+Business Media Dordrecht 2013}

Chapters 4, 5, 6: (C) Springer Science+Business Media Dordrecht (outside the USA) 2013

This work is subject to copyright. All rights are reserved by the Publisher, whether the whole or part of the material is concerned, specifically the rights of translation, reprinting, reuse of illustrations, recitation, broadcasting, reproduction on microfilms or in any other physical way, and transmission or information storage and retrieval, electronic adaptation, computer software, or by similar or dissimilar methodology now known or hereafter developed. Exempted from this legal reservation are brief excerpts in connection with reviews or scholarly analysis or material supplied specifically for the purpose of being entered and executed on a computer system, for exclusive use by the purchaser of the work. Duplication of this publication or parts thereof is permitted only under the provisions of the Copyright Law of the Publisher's location, in its current version, and permission for use must always be obtained from Springer. Permissions for use may be obtained through RightsLink at the Copyright Clearance Center. Violations are liable to prosecution under the respective Copyright Law.

The use of general descriptive names, registered names, trademarks, service marks, etc. in this publication does not imply, even in the absence of a specific statement, that such names are exempt from the relevant protective laws and regulations and therefore free for general use.

While the advice and information in this book are believed to be true and accurate at the date of publication, neither the authors nor the editors nor the publisher can accept any legal responsibility for any errors or omissions that may be made. The publisher makes no warranty, express or implied, with respect to the material contained herein.

Printed on acid-free paper

Springer is part of Springer Science+Business Media (www.springer.com) 


\section{Preface}

Wetlands are generically defined as lentic systems that take on characteristics of both terrestrial and aquatic systems where vegetation capable of growing in shallow water proliferates. However, there are many definitions of wetlands in use around the world, including a number that have ecological and legal significance. Even among these definitions, there are numerous subtle nuances that blur the lines between wetlands and either terrestrial or aquatic systems. Despite the confusion and oftentimes contradictory nature of wetland definitions, wetlands are increasingly being recognized as critical ecosystems throughout the world. In particular, we are seeing an increased awareness about the values and benefits derived from the world's wetlands. As this awareness has grown, we have also seen a greater focus on efforts to better manage, conserve, and protect wetlands. Wetland-related research has been and will continue to be critically important in providing guidance to all the efforts to better manage, conserve, and protect wetlands. In fact, there is a plethora of wetland-related literature available to wetland scientists, regulators, and managers, many of which can be found in at least two journals that are dedicated exclusively to wetlands. However, for most wetland professionals, it may be a daunting task to access much of this literature. Additionally, wetland professionals have not had a book available that covers techniques associated with wetland research, management, and regulation.

The lack of such a book has been a major void in the wetland field. In fact, wetland professionals have discussed for some time the need for a book that focused on wetland research and management techniques. We believe the development of a techniques book for a profession is a sign that the profession, in this case wetland science, is maturing. Scientific progress in a field is often advanced by the development of a techniques book because almost all studies and management actions boil down to choosing appropriate techniques, and a book focused on the topic of wetland techniques will provide fledgling scientists and managers a solid foundation for initiating research and management efforts. We have designed this 
three volume set for students and professionals interested in wetlands ecology, management, and creation. We are pleased to be a part of the development and progression of our discipline through our involvement with the development of Wetland Techniques Volume 1: Foundations, Volume 2: Organisms, and Volume 3: Applications and Management.

West Virginia University

James T. Anderson Morgantown, WV, USA

Oklahoma State University

Craig A. Davis

Stillwater, OK, USA 


\section{Acknowledgments}

Wetland Techniques is our first attempt at a major book project and it was a wonderful learning opportunity as well as an eye-opening experience in regards to all the effort that goes into creating a series of books of this magnitude. We have new-found admiration for all those before us that have successfully tackled book projects for the benefit of science.

We thank the chapter authors for providing freely of their time and expertise. It has been a pleasure working with the authors and we have learned a lot more about wetlands because of them. We thank all of the chapter referees for giving their time and expertise to improve the quality of this three volume Wetland Techniques set through constructive reviews that greatly improved the chapters. We especially thank Rachel Hager, undergraduate student in Wildlife and Fisheries Resources at West Virginia University, for all of her help in formatting and verifying literature citations and performing numerous other tasks to improve the book. We also thank Roseanne Kuzmic, research associate in the Natural Resource Ecology and Management Department at Oklahoma State University, for assistance with verifying literature citations.

The following individuals lent their time and expertise to improving these three volumes by serving as expert reviewers and commenting on one or more chapters: Andrew Burgess, Ann Anderson, John Brooks, Crissa Cooey, Diane DeSteven, Adam Duerr, Walter G. Duffy, Andy Dzialowski, Gordon Goldsborough, Mark Gregory, Kim Haag, Patricia Heglund, Wade Hurt, Paul Koenig, James W. LaBaugh, Ted LaGrange, Richard L. Naff, Chris Noble, Aaron Pearse, James Rentch, Wayne Rosing, Stephen Selego, Ken Sheehan, Lora Smith, Gabe Strain, Jered Studinski, Charles H. Theiling, Walter Veselka, Susan Walls, Lisa Webb, and Nicolas Zegre. 



\section{Contents}

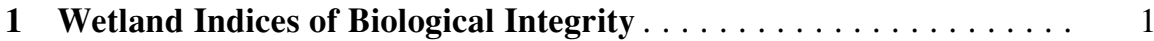
Walter E. Veselka IV and James T. Anderson

2 Hydrogeomorphic Classification and Functional Assessment . . . . . . . . . . . . . . . . . . . . . . . 29

Craig A. Davis, Daniel Dvorett, Joseph R. Bidwell, and Mark M. Brinson

3 Wetland Design and Development . . . . . . . . . . . . . . . . . . 69 Mickey Heitmeyer, Leigh Fredrickson, Murray Laubhan, Frank Nelson, Gary Pogue, Doug Helmers, and Wayne King

4 Management of Wetlands for Wildlife . . . . . . . . . . . . . . . . 121 Matthew J. Gray, Heath M. Hagy, J. Andrew Nyman, and Joshua D. Stafford

5 Ecosystem Services: Developing Sustainable Management Paradigms Based on Wetland Functions and Processes .

Ned H. Euliss Jr., Mark M. Brinson, David M. Mushet, Loren M. Smith, William H. Conner, Virginia R. Burkett, Douglas A. Wilcox,

Mark W. Hester, and Haochi Zheng

6 Planning Interpretive and Education

Programs for Wetlands . . . . . . . . . . . . . . . . . . . . . . . . . . . 229

Dave Smaldone 



\section{Contributors}

James T. Anderson Division of Forestry and Natural Resources \& Environmental Research Center, West Virginia University, Morgantown, WV, USA

Joseph R. Bidwell Discipline of Environmental Science and Management, School of Environmental and Life Sciences, University of Newcastle, Callaghan, NSW, Australia

Virginia R. Burkett U.S. Geological Survey, Climate Change Science Institute, Many, LA, USA

William H. Conner Forestry and Natural Resources, Clemson University, Clemson, SC, USA

Craig A. Davis Department of Natural Resource Ecology and Management, Oklahoma State University, Stillwater, OK, USA

Daniel Dvorett Department of Natural Resource Ecology and Management, Oklahoma State University, Stillwater, OK, USA

Oklahoma Conservation Commission, Oklahoma City, OK, USA

Ned H. Euliss Jr. U.S. Geological Survey, Northern Prairie Wildlife Research Center, Jamestown, ND, USA

Leigh Fredrickson Wetland Management and Education Services, Puxico, MO, USA

Matthew J. Gray Department of Forestry, Wildlife and Fisheries, University of Tennessee, Knoxville, TN, USA

Heath M. Hagy Forbes Biological Station, Illinois Natural History Survey, Havana, IL, USA

Mickey Heitmeyer Greenbrier Wetland Services, Advance, MO, USA

Doug Helmers U.S. Fish and Wildlife Service, Neal Smith NWR, Prairie City, IA, USA 
Mark W. Hester Department of Biology, University of Louisiana-Lafayette, Lafayette, LA, USA

Wayne King U.S. Fish and Wildlife Service, Denver Federal Center, Denver, CO, USA

Murray Laubhan Environmental Services Section, U.S. Fish and Wildlife Service, Pratt, KS, USA

David M. Mushet U.S. Geological Survey, Northern Prairie Wildlife Research Center, Jamestown, ND, USA

Frank Nelson Missouri Department of Conservation, Jackson, MO, USA

J. Andrew Nyman School of Renewable Natural Resources, Louisiana State University, Baton Rouge, LA, USA

Gary Pogue U.S. Fish and Wildlife Service, West Tennessee National Wildlife Refuges Complex, Dyersburg, TN, USA

Dave Smaldone Recreation, Parks and Tourism Resources Program, West Virginia University, Morgantown, WV, USA

Loren M. Smith Department of Zoology, Oklahoma State University, Stillwater, OK, USA

Joshua D. Stafford U.S. Geological Survey, South Dakota Cooperative Fish and Wildlife Research Unit, Department of Natural Resource Management, South Dakota State University, Brookings, SD, USA

Walter E. Veselka IV Division of Forestry and Natural Resources \& Environmental Research Center, West Virginia University, Morgantown, WV, USA

Douglas A. Wilcox Department of Environmental Science and Biology, The College at Brockport State University of New York, Brockport, NY, USA

Haochi Zheng Department of Earth System Science and Policy, University of North Dakota, Grand Forks, ND, USA 